\title{
RESTORATION SUCCESS EVALUATION OF A THINNED AND ENRICHED PINE PLANTATION IN SRI LANKA
}

\author{
Jayawardhane J* \& Gunaratne AMTA \\ Department of Botany, Faculty of Science, University of Peradeniya, Sri Lanka \\ *jayaminijayawardhane1@gmail.com \\ Submitted April 2020; accepted June 2020
}

\begin{abstract}
Enrichment of monoculture plantations with broad-leaved species convert poorly managed exotic plantations into mixed species woodlands with enhanced ecosystem services. However, the effect of enrichment planting on the recruitment of plant diversity is poorly understood. This study aims to investigate the effect of enrichment planting in an eleven-year-old restored Pine (Pinus caribaea Morelet) plantation (RP) and a 25-30-year-old unrestored Pine plantation (UP) in Hantana, Sri Lanka. All naturally regenerated woody species were tagged, identified, and counted. The height and the diameter at breast height were measured. Nearly four times more woody species emerged from RP than UP. However, majority of species in both RP and UP were represented by the exotic invasive tree species Alstonia macrophylla Wall. ex G. Don. The mean density of seedlings of woody species was higher in RP than UP. The Shannon-Wiener diversity index was higher in RP than UP for all different life stages. Endemics were only recorded in RP. Since improved plantation structure and higher diversity was recorded in RP than UP, thinning followed by enrichment planting can be used to restore monoculture Pine plantation into mixed species plantations.
\end{abstract}

Keywords: Pinus caribaea, enrichment planting, mixed species plantations, natural regeneration

\section{INTRODUCTION}

Enrichment planting (EP) using local tree species stabilises eroded lands, conserves biodiversity, sequesters carbon and provides many ecosystem services (Millet et al. 2013). The use of native and endemic species in enrichment planting is a tool to ecologically restore biodiversity and productivity of monoculture plantations (Mangueira et al. 2019).

The south-western part of Sri Lanka and Western Ghats of India are areas in the 34 biodiversity hotspots which is threatened due to tremendous population pressures (Gunawardene et al. 2007). Natural forest cover in Sri Lanka decreased drastically during the colonial era due to plantation agriculture. Thus, in the $1970 \mathrm{~s}$, the Forest Department of Sri Lanka established forest plantations using exotic species in order to protect the existing natural forests and to recover the ecologically damaged areas (Ambagahaduwa 2008). The reforestation of degraded areas with exotic plant species, such as Pinus caribaea, Eucalyptus spp. and Acacia sp., has proven to exert negative impacts on the environment and native biodiversity due to poor management practices in these areas (Ashton et al. 2014). Furthermore, exotic species do not offer valuable ecosystem services to the local communities (Tomimura 2008).

P. caribaea was extensively used for reforestation of degraded areas in the wet zone of Sri Lanka due to its fast establishment and growth under adverse conditions, fire and herbivore resistance, and high economic uses (Nissanka et al. 2005, Ambagahaduwa 2008). However, it exhibits an invasive behavior in mountainous region in Sri Lanka (Medawatte et al. 2008). Its needles contain allelopathic compounds which negatively affect the soil biodiversity and regeneration of native flora. Furthermore, Pine plantations are prone to dry season fires, dry out streams, reduce ground water levels and reduce light to the undergrowth. Low biodiversity is associated with these monoculture plantations since they do not provide resources for animals (Ambagahaduwa 2008, Medawatte et al. 2008, Nissanka et al. 2015). Thus, experimental trials to restore Pine plantations to its native vegetation at Sinharaja and Hantana in Sri Lanka were conducted through thinning of Pine rows and enrichment planting with economically and ecologically important plant species (Ashton et al. 1997, Ambagahaduwa et al. 2009). 
Restoration success in monoculture plantations has been assessed using ecological variables such as growth performance of planted species (Phongoudome et al. 2015, Teuscher et al. 2016) and natural regeneration after restoration efforts (Medawatte et al. 2014). Although there were many records of natural regeneration in Pine plantations in the tropics, such studies were lacking for silviculturally managed Pine plantations. Our objectives were to evaluate the restoration efforts of Pine enrichment in terms of acquiring vegetation structure, floristic composition, diversity, and in establishing ecological processes as compared to an unrestored Pine plantation in Sri Lanka.

\section{MATERIALS AND METHODS}

\section{Study area}

The study was conducted in the Hantana Mountain Range (HMR) ( $7^{\circ} 17^{\prime} \mathrm{N}$ and $80^{\circ} 36^{\prime}$ $\mathrm{E}$, area of $432 \mathrm{ha}$ ) in central Sri Lanka. HMR was declared as an Environmental Protection Area in 2010 due to its significance in biodiversity and hydrology (Ambagahaduwa 2008) (Figure 1). It consists of a series of hills separated by valleys at elevations ranging from $518-1110 \mathrm{~m}$. A total of 397 plant species belonging to 102 families have been recorded in the area. This region has hot and humid climate (Greller et al. 1980) with mean annual temperature of $29.3{ }^{\circ} \mathrm{C}$ and precipitation of $2539.8 \mathrm{~mm}$ in 2014 according to the climatic data collected at the Natural Resource Management Centre, Peradeniya, Sri Lanka.

A larger part of the lower montane forests in HMR was cleared for coffee, rubber and tea plantations in the past. By 1938, most of these lands were abandoned due to their low productivity (Ambagahaduwa 2008). After 1952, some of the abandoned lands were converted to grasslands dominated by Cymbopogon nardus (L.) Rendle while others were converted to secondary forests (Ratnayake 2001). In the 1970s, P. caribaea plantations were established in abandoned sites of HMR by the Forest Department aiming to reduce further degradation of land and to protect water catchments of the Mahaweli river (Ambagahaduwa 2008).

The study site was located $4 \mathrm{~km}$ to the southwest of Kandy city and at the northwestern end of the hill range extending from Hindagala to Peradeniya. The area is moderately to highly steep in topography with an altitude range of 500-700 $\mathrm{m}$. Thinning followed by enrichment planting in a 25-30-year-old $P$. caribaea plantation in Hantana was conducted in 2004 , by using four ecologically and economically valuable broad-leaved tree species; Artocarpus nobilis Thw. (Moraceae), Madhuca longifolia (L.) Macbride (Sapotaceae), Magnolia champaca (L.) Baill. ex Pierre (Magnoliaceae) and Terminalia bellirica (Geartn.) Roxb. (Combretaceae) (Ambagahaduwa et al. 2009). These tree species were planted under the canopy of Pine plantation according to different light treatments by strip cutting of the Pine trees (Ambagahaduwa et al. 2008). In 2009, the remaining Pine trees were removed, and the site was left to regenerate naturally. This site was named as restored Pine plantation (RP). A 25-30-year-old unrestored Pine plantation (UP) at the same elevation range was selected as the control site (Figure 1).

\section{Vegetation sampling}

Fifteen plots of $5 \times 5 \mathrm{~m}^{2}$ were established randomly at each plantation (RP and UP), using GPS points in Arc GIS and a GPS receiver. In each plot, three $1 \times 1 \mathrm{~m}^{2}$ sub plots were established randomly with a total of 45 subplots in each plantation. All seedlings $(<50 \mathrm{~cm}$ in height) located in $1 \times 1 \mathrm{~m}^{2}$ plots, and saplings $(50-300 \mathrm{~cm}$ in height) and trees (>300 cm in height) in $5 \times$ $5 \mathrm{~m}^{2}$ plots were tagged, identified, and counted. The height of all the tree growth stages were measured using a ruler, a pole and a clinometer. A diameter at breast height ( $\mathrm{dbh}$ ) tape was used to measure dbh of stems (saplings and trees) at $1.3 \mathrm{~m}$ above ground level. Plants were identified using plant guides and manuals (Ashton et al. 1997, Vlas \& Vlas 2000). They were categorized into families, genera, species, ecological groups (climax, pioneer and invasive and non-invasive), origin (endemic, native and exotic) and seed dispersal modes (zoochory, anemochory and autochory) by referring to manuals and available literature (Kueffer et al. 2007, Nagaraja et al. 2011, Feroz et al. 2016, Herrera-Peraza et al. 2016, Tripathi et al. 2018).

\section{Data analysis}

Alstonia macrophylla was an outlier in the data set due to its over-dominance in the RP (seedlings $=72 \%$, saplings $=62 \%$, trees $=40 \%)$ and UP $($ seedlings $=44 \%$, saplings $=50 \%$, trees $=74 \%)$. 

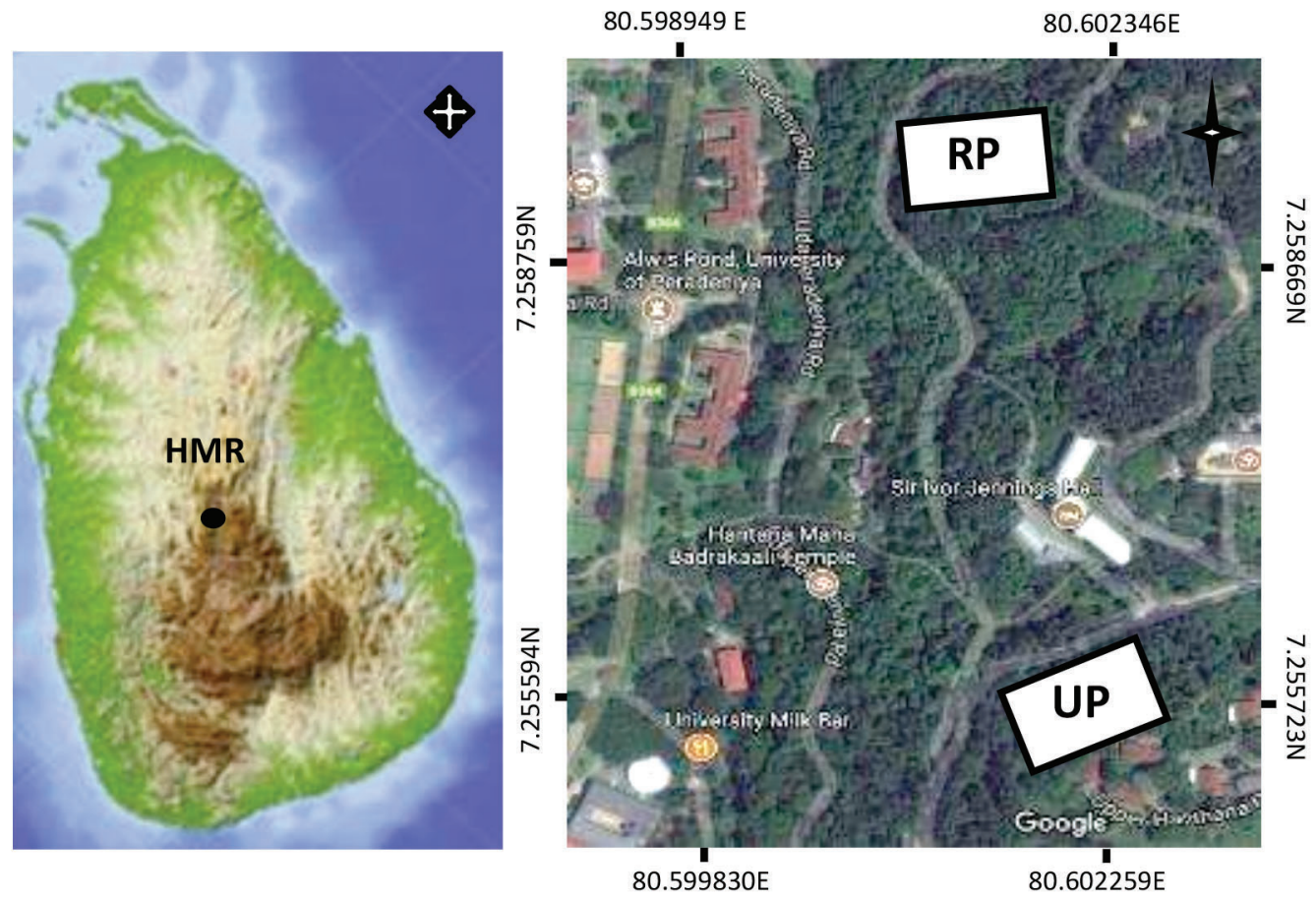

Figure 1 Location map of Hantana Mountain Range (HMR), restored Pine plantation (RP) and unrestored Pine plantation (UP) in HMR, Sri Lanka

Therefore, data on A. macrophylla was only considered for data analysis on invasive species. Data were statistically analyzed using Microsoft Excel 2017 and MINITAB 17. The mean densities were calculated by considering the total number of individuals per sampled area. Two- sampled t-test was conducted to compare the mean densities of woody species between the two plantations. The height class and dbh histograms were constructed to evaluate the population structure of naturally regenerated woody species. Diversity indices were calculated to determine the species diversity of naturally regenerated woody species in both plantations. The ShannonWiener diversity index $\left(H^{\prime}\right)$ and Simpson Index (D) were calculated using the following formulae (Shannon \& Wiener 1963)

$$
H^{\prime}=\sum_{i=1}^{R} p i \ln p i
$$

where,

$R=$ Number of species

$p_{\mathrm{i}}=$ Proportion of one individual or the abundance of $i^{\text {th }}$ species in the community

$\ln =$ Natural $\log$

$$
D=1 / \sum p^{2} i
$$

where

$D=$ Simpson's Diversity Index

$p=$ the proportion of $\mathrm{i}^{\text {th }}$ species in the community

Shannon evenness (J) was calculated by using the formula given below (Pielou 1969).

$$
\mathrm{J}=H^{\prime} / H_{\text {max }}
$$

where

$H_{\max }=$ Maximum value of $H^{\prime}=\ln$ (species richness or number of species)

Species richness accounts for the total number of species recorded in a site. Rank abundance curves were constructed for each site.

\section{RESULTS}

\section{Plantation structure}

The vertical and horizontal structure of the two plantations varied in mean height, number of strata and densities of stems (Table 1, Appendix B). The mean canopy height was higher in UP (20-30 m) than RP (15-20 m). A greater stratification with a developing canopy, dense understory layer and ground layer were observed in RP. Whereas in UP, dense canopy layer, sparse 
understory and ground layer were observed (Appendix B). The mean densities of newly emerged seedlings were significantly higher than saplings and trees in both plantations (Table $1)$. The mean densities of life stages decreased in the order of seedlings, saplings, and trees in RP while in UP as seedling, trees, and sapling respectively. The mean densities of stems representing different $\mathrm{dbh}$ classes were higher in RP than UP (Figure 2A). Except the 0.71-2.8 $\mathrm{cm}$ dbh class in RP, there was no significant difference between other dbh classes between the two plantations. Naturally regenerated nonPine species belonging to $7.01-9.1 \mathrm{~cm}$ category was observed only in UP.

\section{Floristic composition and diversity}

A total of 1169 individuals of naturally regenerated woody species were recorded from both plantations with the species belonging to 23 families, 34 genera and 35 species (Table 2, Appendix C). Euphorbiaceae, Symplocaceae, Myrtaceae and Pittosporaceae were the dominant plant families recorded in both plantations. Nine and four families were recorded exclusively in RP and UP, respectively. Ten species (Albizia odoratissima (L.f.) Benth., A. macrophylla, Ficus hispida L.f., Fillicium decipiens (Wight \& Arn.) Thw., Macaranga peltata (Roxb.) Muell. Arg., Neolitsea cassia (L.) Kosterm, P. caribaea, Pittosporum ferrugineum Dryander ex W.T.Aiton, Psidium guineense Sw. and Symplocos cochinchinensis (Lour.) S. Moore) were common to both plantations. Twenty species and five species were only found in RP and UP, respectively.

Species diversity of seedlings, saplings and trees were higher in RP than UP (Table 2). The Shannon-Weiner and Simpson's indices were higher for seedlings than saplings and trees in

Table 1 Plantation structure and composition of different life stages according to distribution of invasive species and origin of plants in the restored Pine plantation (RP) and unrestored Pine plantation (UP)

\begin{tabular}{ccccccc}
\hline \multirow{2}{*}{ Habitat } & Life stage & \multicolumn{5}{c}{ Mean density (individuals ha ${ }^{-1}$ ) } \\
\cline { 3 - 6 } & Mean density & Invasive species & Endemics & Natives & Exotics \\
\hline \multirow{3}{*}{ RP } & Seedlings & $34000 \pm 25517 \mathrm{a}$ & $91111 \pm 205120 \mathrm{a}$ & $444 \pm 1721 \mathrm{a}$ & $22667 \pm 16581 \mathrm{a}$ & $10889 \pm 12691 \mathrm{a}$ \\
& Saplings & $2240 \pm 1254 \mathrm{~b}$ & $3867 \pm 4705 \mathrm{ab}$ & $267 \pm 103.3 \mathrm{a}$ & $1147 \pm 798 \mathrm{~b}$ & $987 \pm 1199 \mathrm{~b}$ \\
& Trees & $907 \pm 1136 \mathrm{~b}$ & $1067 \pm 1407 \mathrm{~b}$ & $0.00 \pm 0.00 \mathrm{a}$ & $853 \pm 1150 \mathrm{~b}$ & $533 \pm 1407 \mathrm{~b}$ \\
& Seedlings & $28222 \pm 19715 \mathrm{a}$ & $17556 \pm 18015 \mathrm{ab}$ & $0.00 \pm 0.00 \mathrm{a}$ & $18000 \pm 14243 \mathrm{a}$ & $10222 \pm 15403 \mathrm{a}$ \\
$\mathrm{N}$ UP & Saplings & $160 \pm 331.2 \mathrm{~b}$ & $160 \pm 331.2 \mathrm{~b}$ & $0.00 \pm 0.00 \mathrm{a}$ & $133.3 \pm 246.9 \mathrm{~b}$ & $26.7 \pm 103.3 \mathrm{~b}$ \\
& Trees & $293 \pm 440 \mathrm{~b}$ & $1973 \pm 1785 \mathrm{ab}$ & $0.00 \pm 0.00 \mathrm{a}$ & $267 \pm 419 \mathrm{~b}$ & $28.6 \pm 106.9 \mathrm{~b}$ \\
\hline
\end{tabular}

Two-sample t-test, different letters indicate significant differences at $p<0.05$

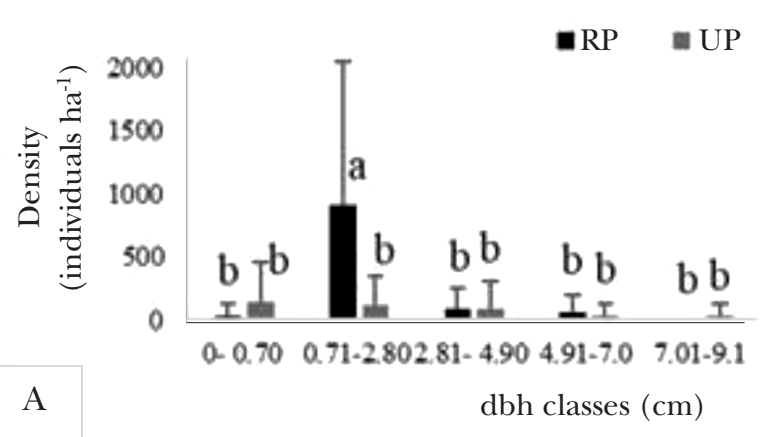

$\mathrm{RP}=$ restored Pine plantation, $\mathrm{UP}=$ unrestored Pine plantation Two-sample t-test, different letters indicate significant differences at $p<0.05$

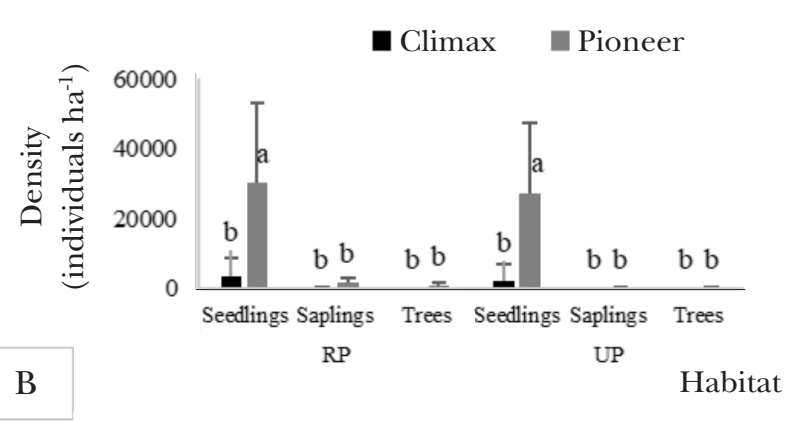

$\mathrm{RP}=$ restored Pine plantation, $\mathrm{UP}=$ unrestored Pine plantation Two-sample t-test, different letters indicate significant differences at $p<0.05$

Figure 2 A) Distribution of dbh classes (mean \pm standard deviation) of species and B) plants belonging to different ecological groups, pioneer or climax in the two plantations 
Table 2 Richness and diversity of different life stages in restored Pine plantation (RP) and unrestored Pine plantation (UP)

\begin{tabular}{|c|c|c|c|c|c|c|c|}
\hline \multirow[b]{2}{*}{ Habitat } & \multirow[b]{2}{*}{ Life stage } & \multicolumn{3}{|c|}{ Number } & \multicolumn{3}{|c|}{ Diversity indices } \\
\hline & & Genera & Family & Species & $\begin{array}{c}\text { Shannon-Wiener } \\
\text { index }\end{array}$ & $\begin{array}{l}\text { Simpson's } \\
\text { index }\end{array}$ & $\begin{array}{l}\text { Shannon } \\
\text { Evenness }\end{array}$ \\
\hline \multirow{3}{*}{$\mathrm{RP}$} & Seedlings & 19 & 15 & 19 & $2.216 \pm 0.102 b$ & $0.156 \pm 0.021 b$ & $0.117 \pm 0.005 d$ \\
\hline & Saplings & 15 & 11 & 15 & $2.067 \pm 0.114 \mathrm{~b}$ & $0.205 \pm 0.032 b$ & $0.138 \pm 0.008 \mathrm{~cd}$ \\
\hline & Trees & 8 & 7 & 8 & $1.466 \pm 0.085 \mathrm{ab}$ & $0.332 \pm 0.107 \mathrm{~b}$ & $0.183 \pm 0.011 b$ \\
\hline \multirow{3}{*}{ UP } & Seedlings & 12 & 12 & 12 & $2.207 \pm 0.095 \mathrm{ab}$ & $0.121 \pm 0.013 \mathrm{~b}$ & $0.184 \pm 0.008 b c$ \\
\hline & Saplings & 5 & 5 & 5 & $1.561 \pm 0.030 \mathrm{a}$ & $0.067 \pm 0.029 b$ & $0.312 \pm 0.006 \mathrm{a}$ \\
\hline & Trees & 3 & 3 & 3 & $0.600 \pm 0.031 \mathrm{ab}$ & $0.655 \pm 0.378 \mathrm{a}$ & $0.200 \pm 0.010 \mathrm{a}$ \\
\hline
\end{tabular}

Two-sample t-test, different letters indicate significant differences at $p<0.05$

both plantations. The Shannon-Weiner diversity index was significantly different for saplings between RP and UP. Shannon evenness index of species representing different life stages varied significantly between the two plantations. Saplings and trees were more evenly distributed in UP than RP.

All the rank abundance curves followed a logseries model (Figure 3). Species abundance of life stages varied between plantations. Seedlings of pioneer species were significantly higher than the saplings and trees of climax species in both plantations (Figure 2B). Seedlings of pioneer species $P$. ferrugineum Dryander and S. cochinchinensis (Lour.) S. and trees of pioneer species M. peltata (Roxb.) Muell. Arg. were dominant in both plantations. Saplings of pioneer species $P$. guineense Sw. and S. cochinchinensis were dominant in RP and UP, respectively.

The native species were significantly higher in both plantations than exotic and endemic species (Table 1). M. peltata and S. cochinchinensis were the dominant native species whilst $P$. guineense was the most abundant exotic species in both plantations. The invasive species A. macrophylla dominated all life stage categories in both plantations (Appendix C). Seedlings and saplings of endemic species Artocarpus nobilis Thw. and Semecarpus nigroviridis Thw. were only recorded in RP.

\section{Seed dispersal mechanisms}

Most of the plant species recorded were zoochorous $(95.1 \%)$ in both plantations, followed by anemochorous (2.6\%) and autochorous (2.3\%) (Figure $4 \mathrm{~A}$ and B). Although more zoochorous species were recorded from RP than UP, the difference between the two plantations was not significant. The seedlings of zoochorous species emerging from RP were significantly higher than other dispersal modes. Trees and saplings of RP were dispersed by animals and wind whereas, all saplings and trees in UP were dispersed by animals. Alstonia scholaris, Peltophorum pterocarpum and $P$. caribaea were the anemochorous species whilst, A. odoratissima and $H$. brasiliensis were the autochorous species recorded.

\section{DISCUSSION}

Monitoring and evaluating restoration success are critical steps in forest management (Kanowski et al. 2010, Derhé et al. 2016). It takes decades to centuries for habitats under reforestation to develop the full structure of a mature forest with floristic composition, well-established structure, high canopy cover and understory (Cunningham et al. 2015).

The overstorey of both plantations were dominated by P. caribaea $(>90 \%)$ and the understory of both plantations were dominated by invasive grass Panicum maximum Jacq (50$85 \%$ ) before the restoration trial started in 2004 (Ambagahaduwa 2008). Our study recorded significantly improved vertical structure and horizontal structure in eleven years after the initiation of restoration in the RP as compared to UP.

According to Lee et al. (2005) seedling recruitment is one of the key indicators used to determine the success of the long-term vegetation restoration (McAlPine et al. 2016). Previous records suggested that the natural 

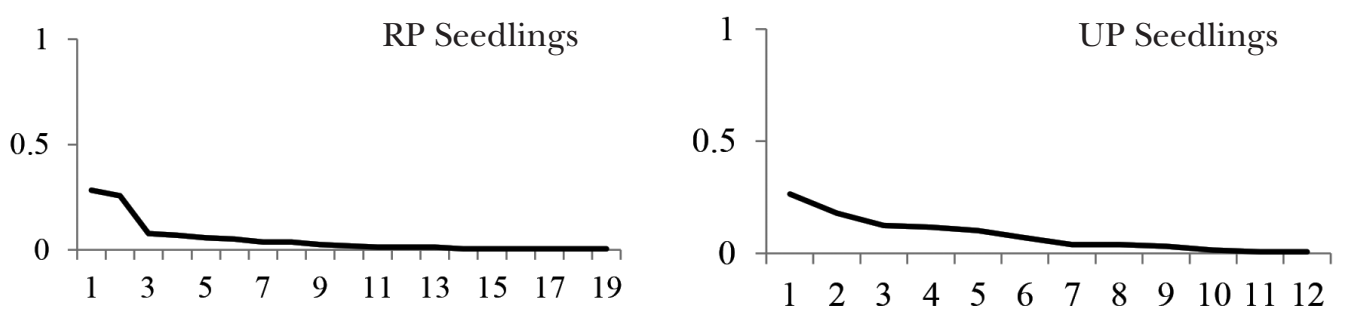
$(1=P$. ferrugenium, $2=S$. cochinchinensis, $3=$ A. odoratissima)

$$
\begin{gathered}
(1=P . \text { ferrugenium, } 2=S . \text { cochinchinensis, } \\
3=M . \text { peltata })
\end{gathered}
$$

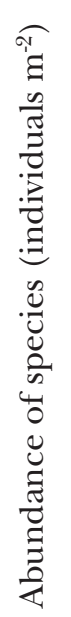
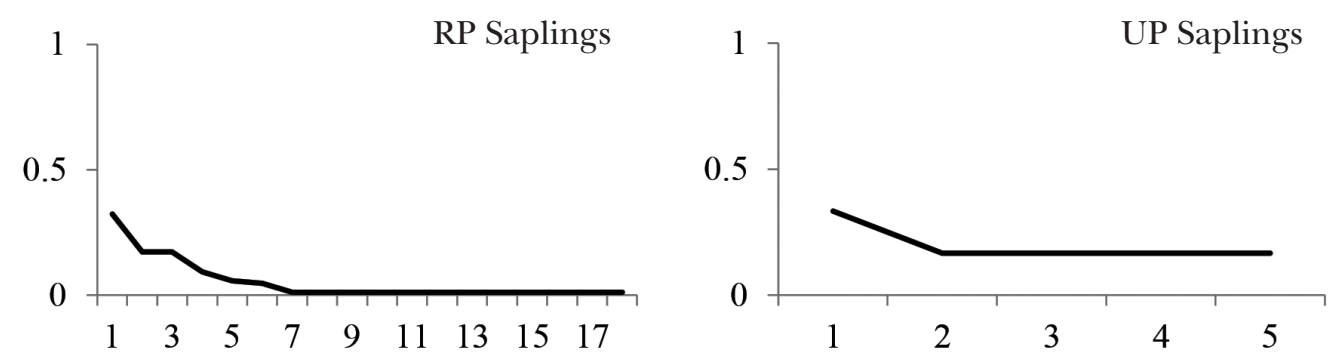

$$
\begin{gathered}
(1=\text { P. guineense, } 2=M . \text { peltata }, \\
3=N . \text { cassia })
\end{gathered}
$$

(1 = S. cochinchinensis, $2=F$. hispida, $3=$ M. peltata, $P$. dichotoma, $P$. ferrugenium)
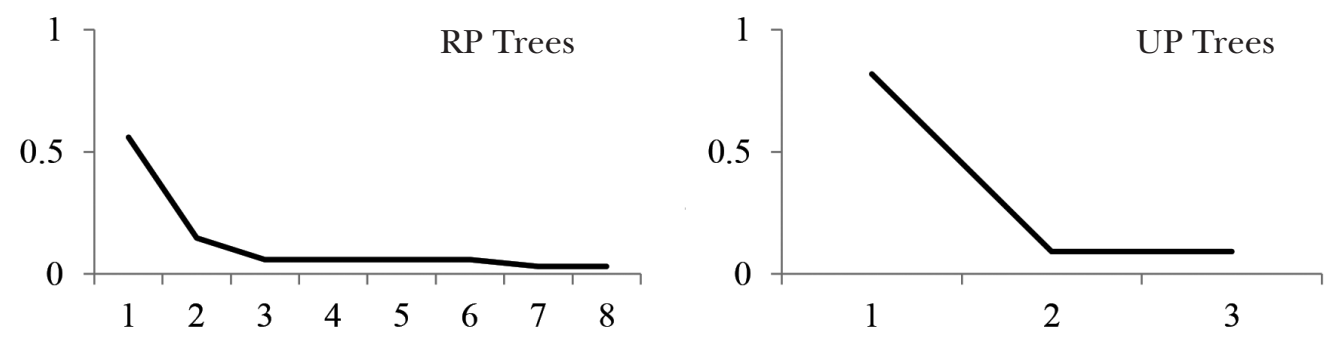

$(1=$ M. peltata, $2=N$. cassia, $3=$ C. spectabilis $)$

Figure 3 Rank abundance curves of seedlings, saplings, and trees of woody species in the two plantations; $(\mathrm{RP}=$ restored Pine plantation and $\mathrm{UP}=$ unrestored Pine plantation $)$

recruitment of plant species in Pine plantations were minimal in Hantana over the 25-30 years of their existence (Ambagahaduwa 2009). Similarly, only a low number of climax species was recorded in 25-30-year-old unrestored Pine plantation in Sinharaja Man and Biosphere Reserve (MAB), Sri Lanka (Tomimura 2008). A comparatively higher density of seedlings and individuals representing $0.71-2.8 \mathrm{~cm}$ dbh group were recorded in $\mathrm{RP}$, indicating natural recruitment levels in RP was greater than that of UP. This might probably be due to changes in light environment beneath the canopy and soil caused by canopy opening and enrichment planting with four broad-leaved species. Thus, improvement of microhabitat conditions in RP might have facilitated the arrival of seeds and enhanced the seed germination and seedling establishment (Crouzeilles et al. 2017).

According to Lee et al. (2005), even after 40 years of establishment, only few pioneer shrub species had regenerated in Pine plantations due to poor soil conditions and lack of seed source in Hong Kong. Additionally, in Sri Lanka the unrestored Pine plantations had lower soil fertility, organic matter and acidity compared to RP (Weerasinghe et al. 2014). Thus, improved 


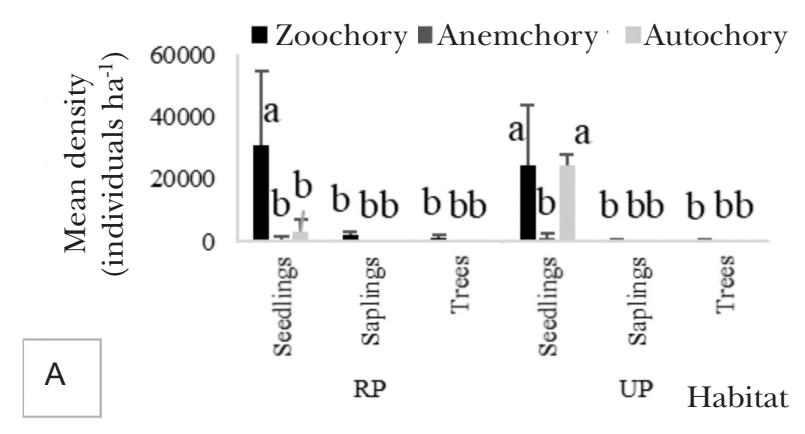

Two-sample t-test, different letters indicate significant differences at $p<0.05$

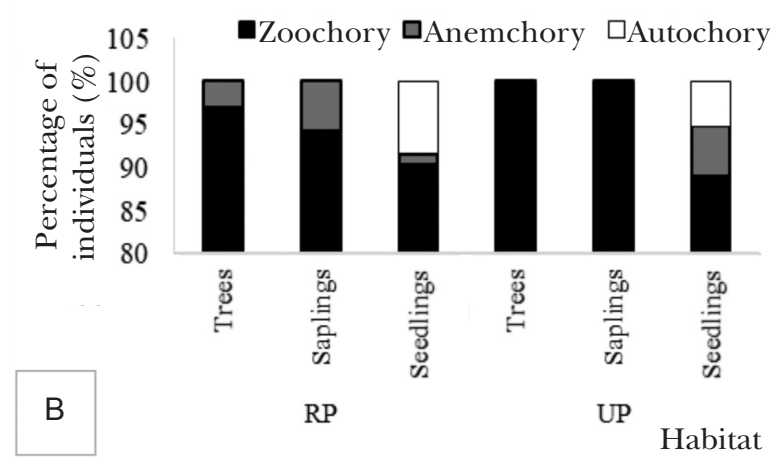

Two-sample t-test, different letters indicate significant differences at $p<0.05$

Figure 4 Seed dispersal mode of different life stages recorded during the study period. $(\mathrm{RP}=$ restored Pine plantation and $\mathrm{UP}=$ unrestored Pine plantation $)$

edaphic factors may have promoted natural regeneration in RP.

Enrichment planting (EP) combines both artificial planting and management of the existing forest matrix, maintaining vegetation structure which consists of different layers and complex assemblages of plants (Michon et al. 2007). Similar to our findings, higher species richness and diversity were recorded in RP than UP and many studies reported that thinning and EP were able to alter the understory vegetation and enhance plant species richness (Dodson et al. 2008, Ares et al. 2010) .

Out of 30 species recorded in RP, 28 species were new to the plantation. Most of the newly recruited species in both RP and UP could be found in the adjacent secondary forests in the area. The presence of native and early successional pioneer species such as $M$. peltata and S. cochinchinensis indicate that RP is in an early successional stage.

The attractiveness of forest plantations to frugivores facilitated the dispersal of propagules into the plantation. Restored habitats adjacent to the existing remnant forest recovered quickly because of their colonization by animal-dispersed seeds (Monie et al. 2013, Abiyu et al. 2016). Our findings reported that the newly recruited species of both plantations were dominated by zoochorous species. This may be due to their proximity to the secondary forest patches, which acted as seed sources for the two plantations. According to Zamora et al. (2010), the occurrence of frugivorous birds in Pine plantations were influenced by the adjacent vegetation in Sierra Nevada of southeast Spain. Unlike wind dispersed Pines, the four tree species used for enrichment planting in RP were zoophiles which attracted seed dispersers to RP. A higher bird diversity was recorded in RP compared to UP in Sri Lanka (Hemage et al. 2011). During the study period, activities of mammals including Toque monkey (Macaca sinica L.), Ceylon blacknaped hare (Lepus nigricollis F. Cuvier), Indian porcupine (Hystrix indica Kerr), Indian wild pig (Sus scrofacristatus Wagne) and barking deer (Muntiacus muntjacZimmermann) were observed in both plantations and they might act as seed dispersers. A higher frequency of animal activities was recorded in RP than in UP, indicating that $\mathrm{RP}$ provides more resources than UP for animal survival.

The spread of invasive plants could lead to failures of forest restoration projects, if management is inadequate or unsuitable (Kanowski et al. 2010, Simmons et al. 2016). A. macrophylla is a fast-growing invasive pioneer species with adaptations to grow well in nutrientpoor soils (Weerawardane \& Dissanayake 2005). The dominance of A. macrophylla in both plantations threatens the regeneration of native flora due to inter-specific competition for above and below ground resources (Tomimura 2008). Thick understory formed by the invasive species, Clidemia hirta (L.) D. Don, at the edges of RP and in edges and interior of UP threatens the emergence and establishment of new recruits in both plantations. Thus, effective management practices are needed to monitor, evaluate and manage these invasive species in order to achieve success in forest restoration. Since Pine plantations in the mountainous region of Sri Lanka are frequently burnt during the dry season, causing many negative environmental impacts, 
it is of utmost importance to use silvicultural treatments to restore them into less flammable ecosystems such as mixed species plantations that can provide a variety of ecosystem services of local importance.

\section{CONCLUSIONS}

Restoration efforts by means of thinning followed by enrichment planting with broadleaved species enhanced the plantation structure and floristic composition in Pine plantations in mountainous regions of Sri Lanka. The use of multiple indicators such as vegetation structure, floristic composition, species diversity and seed dispersal mechanisms provided valuable insights into the ongoing ecological trajectories and enabled the identification of necessary future management interventions. Invasion of A. macrophylla must be managed and monitored to achieve restoration success. Thinning and enrichment planting can be used to restore monoculture Pine plantations to mixed species woodlands in central Sri Lanka.

\section{ACKNOWLEDGEMENT}

The authors expressed their gratitude to Natural Resources Centre, University of Peradeniya, Sri Lanka for providing climatic data of the region. We thank Mr. M.G. Jayaratne, Ms. L.M.M. Upeksha, Ms. K.K.Y. Dilhani and Mr. R.E.B.L.A. Gunnepana for field assistance, Prof. K.M.G. Jayasuriya for the assistance in data analysis and Ms. Carly Penton for manuscript editing.

\section{REFERENGES}

Abiyu A, Teketay D, Glatzel G et Al. 2016. Seed production, seed dispersal and seedling establishment of two afromontane tree species in and around a church forest: Implications for forest restoration. Forest Ecosystems 1: 16-25. https://doi.org/10.1186/ s40663-016-0076-5.

Ambagahaduwa IM. 2008. Restoration of plant diversity in monoculture Pinus plantations in Sri Lanka. MPhil thesis, Postgraduate Institute of Science, University of Peradeniya, Sri Lanka.

Ambagahaduwa IM, Prasad N, Gunatilleke IAUN et al. 2009. Estimation of above ground biomass of a Pinus caribaea Morelet plantation in lower Hantana. Journal of National Science Foundation 37: 195-201. https://doi.org/10.4038/jnsfsr.v37i3.1213.

Ares A, Neill AR \& Puettmann KJ. 2010. Understory abundance, species diversity and functional attribute response to thinning in coniferous plantations.
Journal of Forest Ecology and Management 260: 1104-1113. https://doi.org/10.1016/j. foreco.2010.06.023.

Ashton MS, Gunatilleke S, De Zoysa N et al. 1997. A field guide to the common trees and shrubs of Sri Lanka, WHT Publications, Colombo.

Ashton MS, Gunatilleke CVS, Gunatilleke IAUN et al. 2014. Restoration of rain forest beneath Pine plantations: A relay floristic model with special application to tropical South Asia. Forest Ecology and Management 329: 351-359. https://doi.org/10.1016/j. foreco.2014.02.043.

Crouzeilles R, Ferreira MS, Chazdon RL et al. 2017. Ecological restoration success is higher for natural regeneration than for active restoration in tropical forests. Science Advances 3: 1-7. https://doi. org/10.1126/sciadv.1701345.

Cunningham SC, Mac Nally R, Baker PJ et al. 2015. Balancing the environmental benefits of reforestation in agricultural regions. Perspectives in Plant Ecology, Evolution and Systematics 17: 301-317. https://doi. org/10.1016/j.ppees.2015.06.001.

Derhé MA, Murphy H, Monteith G et Al. 2016. Measuring the success of reforestation for restoring biodiversity and ecosystem functioning. Journal of Applied Ecology 53: 1714-1724. https://doi.org/10.1111/13652664.12728.

Dodson EK, Peterson DW \& Harrod RJ. 2008. Understory vegetation response to thinning and burning restoration treatments in dry conifer forests of the eastern Cascades, USA. Forest Ecology and Management 255: 3130-3140. https://doi.org/10.1016/j. foreco.2008.01.026.

Feroz S, Al Mamun A \& Md Enamul Kabir. 2016. Composition, diversity, and distribution of woody species in relation to vertical stratification of a tropical wet evergreen forest in Bangladesh. Global ecology and conservation 8: 144-153. https://doi.org/10.1016/j. gecco.2016.08.012.

Gunawardene NR, Daniels AED, Gunatilleke IAUN et al. 2007. A brief overview of the Western Ghats - Sri Lanka biodiversity hotspot. Current Science 9311: $1567-1572$.

Greller AM, Gunatilleke CVS, Gunatilleke IAUN et al. 1980. A phytosociological analysis of three strands of forests in the vicinity of Peradeniya, Kandy district. The Sri Lanka Forester 14: 153-161.

Hemage KRD, Gunaratne AMTA \& Meegaskumbura M. 2011. Bird-plant interactions and bird diversity in unrestored and restoring habitats in Lower Hantana. p 136 in Proceedings of the Annual Research Sessions, 24th November University of Peradeniya, Sri Lanka. URI: http://dlib.pdn.ac.lk/handle/1/6483.

Herrera-Peraza RA, Bever Jd, Manuel De Miguel J et al. 2016. A new hypothesis on humid and dry tropical forests succession. Acta Botánica Cubana 215: 232-280.

Kanowski J, Catterall CP, Freebody K et al. 2010. Monitoring Revegetation Projects in Rainforest Landscapes: Toolkit Version 3. Reef and Rainforest Research Centre Ltd. Cairns, Australia.

Kueffer C, Schumacher E, Fleischmann K et al. 2007. Strong below-ground competition shapes tree regeneration 
in invasive Cinnamomum verum forests. The Journal of Ecology 95: 273-282. https://doi.org/10.1111/ j.1365-2745.2007.01213.x.

LEe EWS, HAu BCH \& CORLETT RT. 2005. Natural regeneration in exotic tree plantations in Hong Kong, China. Forest Ecology and Management 212: 358-366. https://doi. org/10.1016/j.foreco.2005.03.057.

Mangueira JRSA, Holl KH \& Rodrigues RR. 2019. Enrichment planting to restore degraded tropical forest fragments in Brazil. Ecosystems and People 15: 3-10. https://doi.org/10.1080/21513732.2018.15 29707.

Mcalpine C, Catterall CP, Nally RM et al. 2016. Integrating plant-and-animal-based perspectives for more effective restoration of biodiversity. Frontier Ecology and Environment 14: 37-45. https://doi.org/10.1002/160108.1

Medawatte WWMaB, Tennakoon KU, Hulme PE et al. 2008. Is Caribbean Pine Invading Grasslands in Knuckles Forest Range? Pp. 131-140 in Marambe B. ET AL. (Eds) Invasive Alien Species - Strengthening Capacity to Control the Introduction and Spread of Invasive Alien Species in Sri Lanka. UNDP \& Biodiversity Secretariat Publication.

Medawatte WWMBA, Amarasinghe J, Igbal MCM et al. 2014. Restoration of a degraded dry forest using nurse trees at Dambulla, Sri Lanka. Conservation Evidence 11: 16-19.

Michon G, Levang P \& Verdeaux F. 2007. Domestic forests: a new paradigm for integrating local communities' forestry into tropical forest science. Ecology and Society 12: 1-24. https://doi.org/10.5751/ES-02058-120201

Millet J, Tran N, Ngoc VN et al. 2013. Enrichment planting of native species for biodiversity conservation in a logged tree plantation in Vietnam. New Forests 44: 369-383. https://doi.org/10.1007/s11056-0129344-6

Monie K, Florentine S \& Palmer G. 2013. Plant recruitment and functionality traits as bioindicators of ecological restoration success in the Lurg Hills district, Victoria, Australia. Ecological Process 2: 27-38. https://doi. org/10.1186/2192-1709-2-27

Nagaraja BC, Bunty Raj M, Kavitha A et al. 2011. Impact of rural community harvesting practices on plant biodiversity in Kudremukh National Park, India. International Journal of Biodiversity Science, Ecosystem Services Eं Management 7: 69-74. https://doi.org/ $10.1080 / 21513732.2011 .588184$

Nissanka SP, Монотti KM \& Wijetunga ASTB. 2005. Alleopathic influences of Pinus caribea on vegetation regeneration and soil biodiversity in Proceedings of the Fourth World Congress on Allelopathy, 21-26 August 2005. Wagga Wagga, N.S.W., Australia. http://www. regional.org.au/au/allelopathy/2005/2/1/2415_ nissankasp.htm

Phongoudome C, Sawathvong S, Woo SYet al. 2015. Effects of Enrichment Planting with Five Native Species and Different Plantation Treatments on Seedling Growth Characteristics at Logged-over Forest in Lao PDR [2012]. AGRIS: International Information System for the Agricultural Science and Technology 14: 45-52. https:/ / doi.org/10.5532/KJAFM.2012.14.2.045

PIElou EC.1969. An introduction to mathematical ecology, Wiley, New York.

RATNAYAKE RMCS. 2001. Floristic and soil nutrient status of Hantana forests, Sri Lanka. MPhil thesis, University of Peradeniya, Sri Lanka.

SHANNON CE \& WIENER WW. 1963. The mathematical theory of communications. University of Illinois, Urbana.

Simmons BL, Hallet RA, Sonti NF et al. 2016. Longterm outcomes of forest restoration in urban park. Restoration Ecology 24: 109-118. https://doi. org/10.1111/rec.12281

Teuscher M, Gérard A, Brose U et al. 2016. Experimental Biodiversity Enrichment in Oil-Palm-Dominated Landscapes in Indonesia. Plant Science 7: 1-15. https://doi.org/10.3389/fpls.2016.01538

Tripathi S, Bhadouria R, Srivastava P et al. 2018. The effects of interacting gradient of irradiance and water on seedlings of five tropical dry forest tree species. Tropical Ecology 59: 489-504.

Tomimura C. 2008. Natural succession in Caribbean Pine plantations in Sri Lanka. The bulletin of the Yale tropical resources institute 27: 35-42. https:/ / www.yale.edu/tri

VLAS J \& VLAS J. 2000. Illustrated field guide to the flowers of Sri Lanka. Mark Booksellers and Distributors Pte. Ltd, Kandy.

Weerasinghe AMCP, Gunaratne AMTA \& Madawala HMSP. 2014. Abundance and diversity of soil seed banks of different land use types in upper Hantana, Sri Lanka in Proceedings of the International Forestry and Environment symposium, Department of Forestry and Environmental Science, University of Jayawardenepura, October 2014, Sri Lanka. https:/ / doi.org/10.13140/2.1.3260.3841

WeErawardane NDR \& Dissanayake J. 2005. Status of forest invasive species in Sri Lanka. Pp. 114-120 in McKenzie P, Brown C, Jianghua S. et al. (eds). Proceedings of the Asia Pacific Forest Invasive Species Conference, August 2005, FAO Regional Office for Asia and the Pacific, Bangkok, Thailand.

Zamora R, Hodar JA, Matias L et al. 2010. Positive adjacency effects mediated by seed disperser birds in Pine plantations. Ecological Application 204: 1053-60. https://doi.org/10.1890/09-0055.1 
Appendix A Experimental design of the two Pine plantations ( RP = restored plantation and $\mathrm{UP}=$ unrestored plantation) in Hantana, Sri Lanka

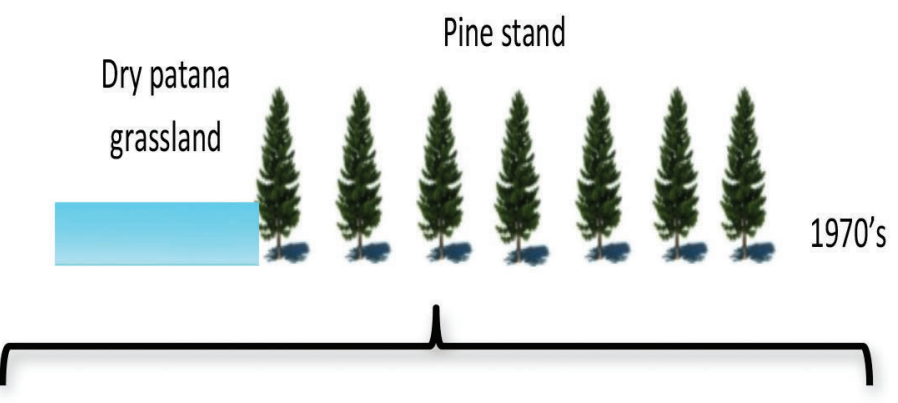

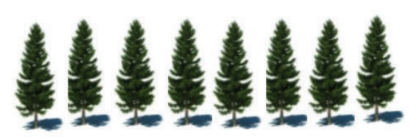

Control site (old Pinus caribaea Morelet plantations from 2003 to

UP

$=$ Pinus caribaed
plantations

$=$ Transplanted native, exotic and endemic species

$\because$

$=$ Other naturally regenerated plant species

$\mathbf{F L}=$ Full light - control trial

FS $=$ Full shade

PS $=$ Partial shade removing 03 pine rows

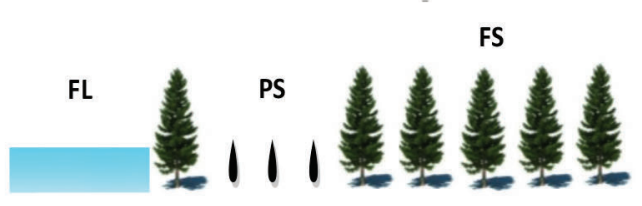

Thinning in Pinus plantations, 2003
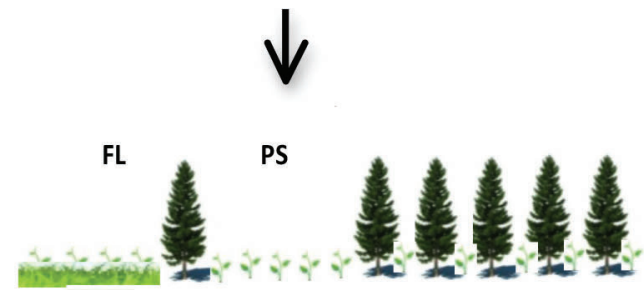

Transplanted native, exotic and endemic species, 2004

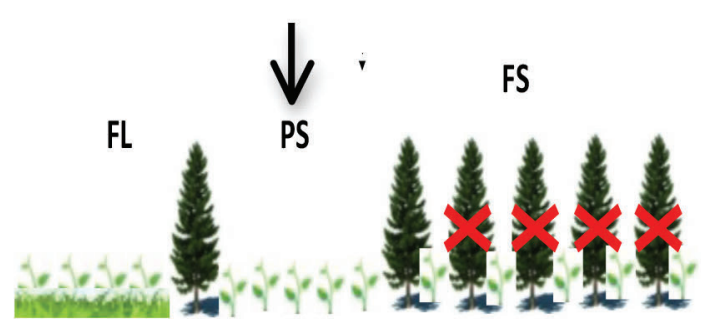

Removal of existing Pinus trees, 2009

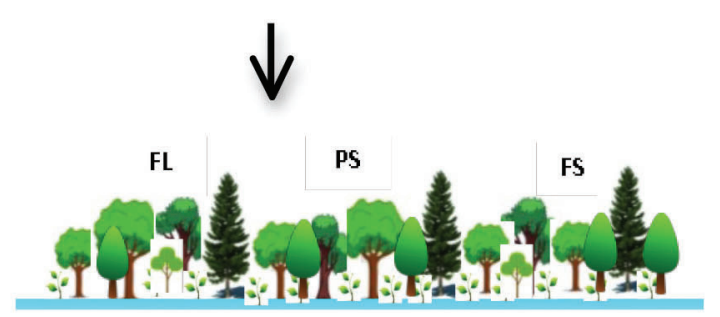

Natural succession under thinned and enriched Pinus plantations, 2015

\section{RP}


Appendix B Profile diagrams of the two Pine plantations ( RP = restored Pine plantation and $\mathrm{UP}=$ unrestored Pine plantation)

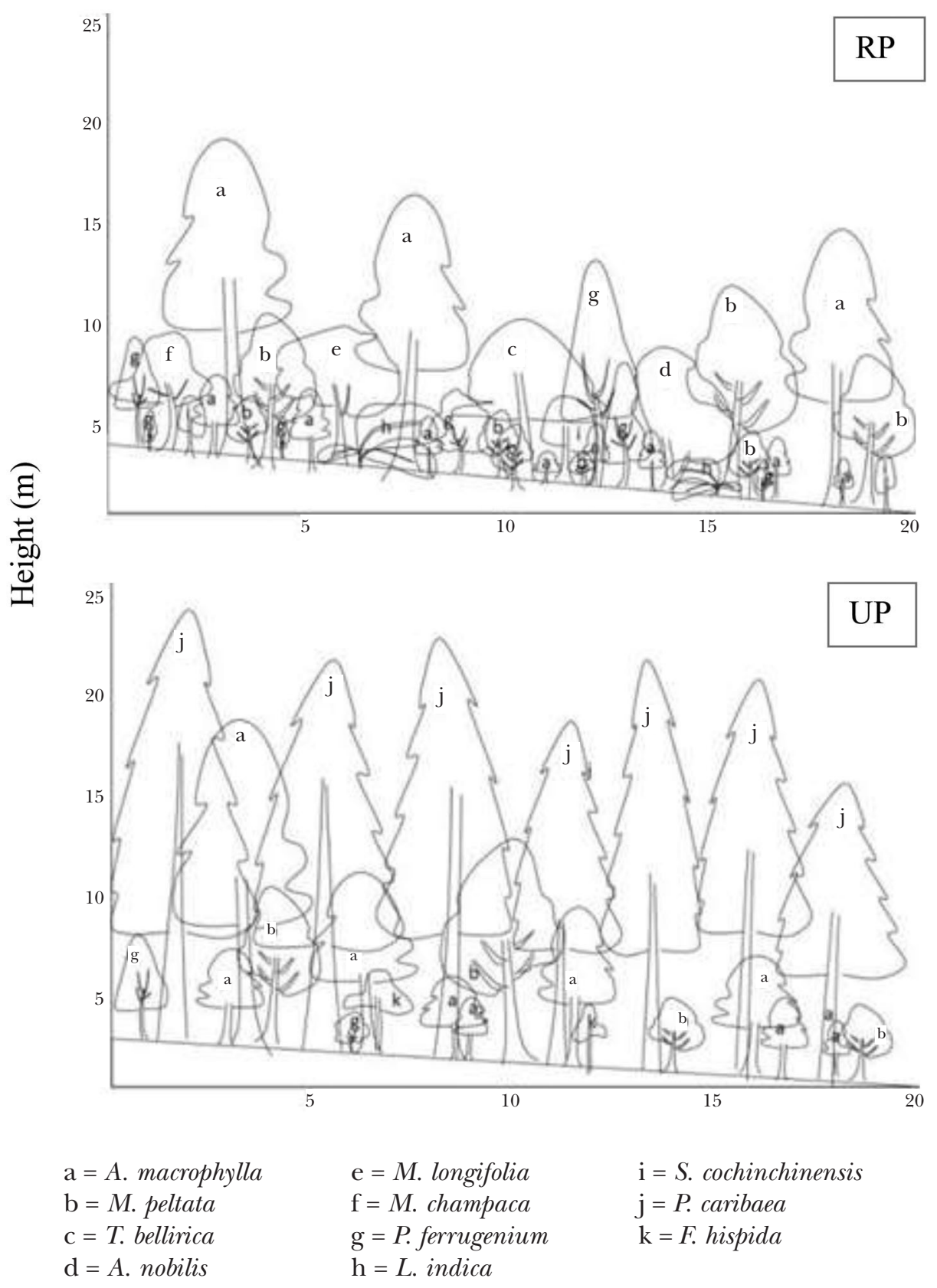




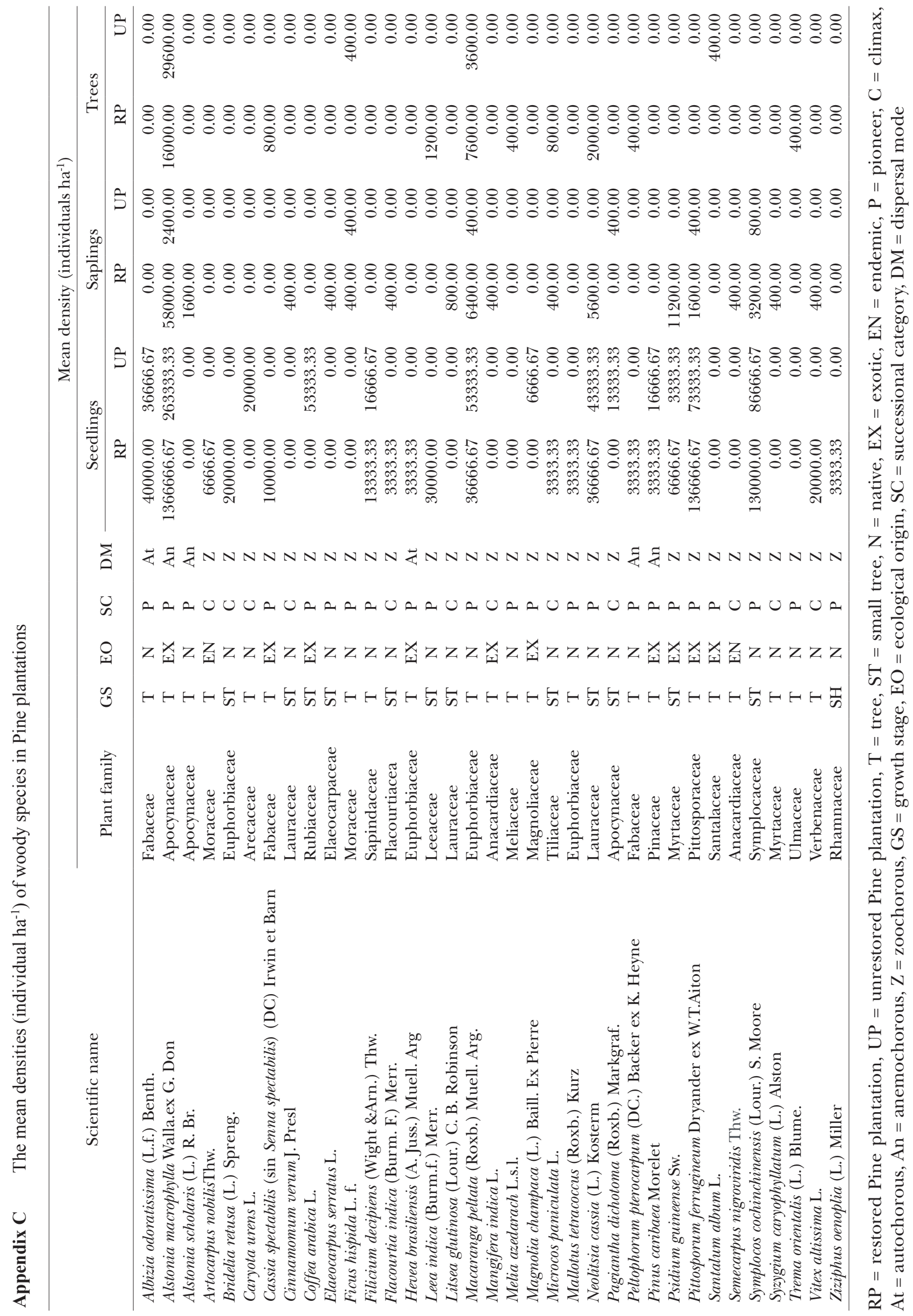

